The Gendering of Global Citizenship: findings from a large-scale quantitative study on global citizenship education experiences

Roland Tormey, Centre de Recherche et d'Appui pour Formation et ses Technologies

(CRAFT), École polytechnique fédérale de Lausanne, Switzerland

Jim Gleeson, Department of Education and Professional Studies, University of Limerick, Ireland

(post-print version

Published in Gender and Education Volume 24, Issue 6, 2012, pp.627-645

http://www.tandfonline.com/doi/abs/10.1080/09540253.2011.646960) 


\title{
The Gendering of Global Citizenship: findings from a large-scale quantitative study on global citizenship education experiences
}

\begin{abstract}
The growing literature on the gendering of citizenship and citizenship education highlights that western notions of 'citizenship' have often been framed in a way that implicitly excludes women. At the same time, insofar as feminist writers have addressed citizenship, they have tended to see it in largely local and national terms. While feminist literature has laid the groundwork for understanding how schools have shaped and structured a gendered citizenry, there is a lack of large-scale quantitative data which might allow us to explore the intersection between gender and global citizenship education. Drawing on a large-scale quantitative study on development education/ global citizenship education in second-level schools, the data presented here suggests that emergent notions of global citizenship are being gendered in schools. The data suggests that single-sex girls' school are more likely than other types of school to emphasise a sense of responsibility for, and an analysis of, global inequalities, while differences also emerge between boys' schools and co-educational schools.
\end{abstract}

Keywords: development education; citizenship education; single-sex schools; gender; Catholic education 


\section{The Gendering of Global Citizenship: findings from a large-scale quantitative study on global citizenship education experiences}

\section{Introduction}

There has been some attention in recent years paid to the way in which gender and citizenship education interact in school settings (Arnot and Dillabough 2000; Fennell and Arnot 2008). This literature highlights the extent to which western notions of ‘citizenship’ have historically been framed in a way that implicitly excludes women. It also shows that feminist researchers have tended, in response, not to engage with citizenship education (Arnot and Dillabough 2000, 14). At the same time, many studies (Lynch 1989c; Mac an Ghaill 1994; Lynch and Lodge 2002 among others) highlight the ways in which gender appropriate social roles are developed by young people in school contexts. Lynch and Lodge $(2002,104)$ have argued, for example, that girls in single-sex schools are socialised to be nurturers and carers, though they argued that the emphasis on caring in girls' schools was in decline when compared to Lynch's earlier (1989a,b,c) study. While this literature has laid the groundwork for understanding how schools have shaped and structured a gendered citizenry, it is notable that the notions of citizenship with which it engages are primarily local and national, that is, they lack reference to the increasingly globalised notions of citizenship which are found in western societies (On Lee 2002; Tormey 2006).

Based on a large quantitative study of 119 schools and over 2,500 pupils, this paper explores the ways in which different types of schools provide different experiences of global citizenship education for both male and female pupils. The paper highlights differences between schools' stated commitment to global citizenship or development education and their practices, and shows how these differences are gendered. The data shows that while single-sex boys' schools are among those most likely to state a strong commitment to global citizenship education or development education, they are among those least likely to offer educational experiences dealing with global poverty and inequality. Single-sex girls' schools are most likely to offer such experiences. This focus on global social responsibility in girls' schools may be related to a Christian Communitarian tradition within female Catholic religious orders (O’Sullivan 2005).

This paper arises out of a research project jointly undertaken by Shannon Curriculum Development Centre and the Curriculum Evaluation and Policy Research 
Unit at the University of Limerick on behalf of Irish Aid (the Irish Government's body with responsibility for overseas development aid and development education). Drawing on a large representative sample of Irish schools, teachers and young people, the purpose of the study was to benchmark current development education practice in Ireland (see Gleeson et al., 2007). Development education is defined as an educational process which aims,

...to enable people to participate in the development of their community, their nation and their world as a whole. Such participation implies a critical awareness of local, national and international situations based on an understanding of social, economic and political processes (UNESCO, cited in Regan and Sinclair 2006, 108).

Development education has been part of the educational landscape in many countries for the last forty years (Hogan and Tormey 2008; Bourn 2008). Although the term 'development education' is commonly used in English-speaking countries to describe formal and informal educational practices that aim to raise awareness of and critical thinking on global poverty, inequality, human rights abuses and other development issues and to encourage learners to be active in relation to such issues, it has not been widely used in academic literature (see Osler 1994; Tormey 2003 and Bourn 2008 as the only three significant academic collections on the topic). Following the Crick reforms in the UK, an academic literature has grown using the term 'global citizenship education' to describe essentially the same type of educational process. At the same time, for both funding and ideological reasons, there remains a commitment to the use of the term 'development education' among some activists and writers. This has meant that, while the terms 'development education' and 'global citizenship education' are typically indistinguishable in practice, separate bodies of literature exist around the two terms. In this paper, the two terms are regarded as effectively synonymous and both bodies of literature are explored.

\section{Gendering Global Citizenship}

Citizenship can be defined as "a particular set of political practices involving specific public rights and duties with respect to a given political community” (Bellamy 2008, 3). Despite the neatness of this definition, it is precisely the questions of "what practices?”, “what rights and duties?” and "who belongs to the community?” that gives citizenship its contested nature (Voet 1998; Hobson and Lister 2002; Lister 2003; Tormey, 2006). For Bellamy, the notion of political community is, at present, 
being transformed by the twin impacts of globalisation and multiculturalism (2008, 3), with the idea of the nation as a political community being fractured, as the construction of identity and identities moves centre stage (Giddens 1991). Seeing the political community as an 'imagined community’ (Anderson 1983), has enabled some to promote a process of imagining notions of community that are rooted in a cosmopolitan identity (Appiah 2006) or a globally sensitive patriotism (Nussbaum 2008). Osler and Starkey use the term 'cosmopolitan citizenship’ for this phenomenon which they define in the following terms:

Citizenship involves making connections between our status and identities as individuals and the lives and concerns of others with whom we share a sense of community. We are increasingly able to make these connections and feel solidarity with others at local, national, regional (e.g. European) and global levels. There are now more ways of being a citizen than have previously been recognised $(2005,8)$.

While they have garnered most attention, globalisation and multiculturalism have not been alone in challenging traditional ideas of citizenship. Arnot and Dillabough have argued that western notions of citizenship tended to be framed around a 'rational' and public actor, something which implicitly excluded the emotional and family dimensions of social life in which women were often most active; they note: "any analysis which drew upon conventional notions of citizenship would most likely fail to take account of women as citizens” $(2000,5)$. Feminist historical sociology (Lentin 1998; Daly 2003; O’Connor 2008 for example), has illustrated this by exploring the ways in which citizenship has been gendered both within constitutional and in legislative terms. Lister has argued that, from a feminist perspective, the idea of 'care' should be seen as central to citizenship; both in the sense that there is a need to pay attention to care for others (especially but not exclusively childcare) which impacts upon women's capacity to participate in the public sphere (2003, 182-190) and secondly in the sense that it is argued that an 'ethic of care' (Gilligan 1982) is an essential component (alongside an 'ethic of justice') of the moral reasoning and acting that should be implicit in notions of citizenship (Lister 2003, 101-116). The concept of an ethic of care is sometimes seen as a necessary corrective to notions of obligation and duty which are seen as inordinately individualistic and insufficiently relational (Hobson and Lister 2002, 33). The focus on obligations is regarded as having had a resurgence through the communitarian influences of Blair, Giddens and the 'Third Way' movement (Hobson and Lister 
2002, 31-36), although it is also evident in the Christian Communitarian tradition (O’Sullivan 2005).

Just as with the wider citizenship literature, the literature on citizenship education, global citizenship education and development education has tended to ignore gender. This is perhaps made all the more striking by the fact that global citizenship education and development education content often deals with the intersection between global development and gender. For example, a review of articles published in development education journals shows that in the years 1994 to 2005 only a single article in The Development Education Journal had a reference to gender in its title, while no article in the journal Policy and Practice: a Development Education Review (which published twelve volumes between 2005 and 2011) has dealt in any significant way with the ways in which learner's engagement in development education is gendered. Likewise, in the three edited volumes on development education identified above (Osler 1994; Tormey 2003 and Bourn 2008) only one chapter makes any reference to the way in which the learner's engagement in development education is gendered (Asbrand 2008). Asbrand's, work, which is based on a qualitative study of what appears to be a relatively small group of schools in Germany, highlights that female and male students differ in their approaches to engagement in extra-curricular development education activities in school. In her study the boys tended to show a need for clarity in outcomes before engaging in such activities, while girls tended to engage in such activities, at least initially, in order have a framework for socialising with each other.

References to gender are equally scarce in the growing global citizenship education literature: Recent studies by Ibrahim (2005), by Davies et al. (2005) and by Osler and Starkey (2005) have, for example, critically discussed aspects of global citizenship education but again the gendering of such education tends to be ignored. Drawing on ideas of Gilligan and Noddings (2003), McIntosh (2005) does seek to link gender and global citizenship and argues that the emotional and care giving tasks associated with women are fundamental in developing an environment of global citizenship and cooperation. For her, what global citizenship requires is, "teachers bringing the wholeness of their emotions and capacities into classrooms... when they work for the decent survival of all” (2005, 39). However, while McIntosh's work connects gendered notions of citizenship with the global, her approach is broadly philosophical and normative and she does not present data on practices in schools. 
This is not to suggest that there are no studies which might give us an insight into how notions of what are appropriate social roles for males and females are formed within educational contexts. Studies by Mac an Ghaill (1994) and Lynch and Lodge (2002) among others highlight the ways in which gender appropriate social roles are developed by young people in school contexts. Lynch and Lodge (2002, 95) identify that the ethos of single-sex girls' schools is an under-researched area. They identify that while a sense of care for self, for the community and others was a pervasive part of the hidden curriculum in girls' schools in the past (Lynch 1989a, b, c) more recent studies have noted a decline in this practice. In comparison, the hidden curriculum of single-sex boys' schools tended to emphasise competition between boys, in academic life and in sporting pursuits, and little appears to have changed from Lynch's (1989) earlier study which found that the "personal and emotional needs of self, family and others are commonly treated as incidentals in men's lives” (Drudy and Lynch 1993, 185). The generation of a sense of care for others is clearly related to the development of a particular and gendered sense of citizenship in which the modes of being traditionally associated with the private sphere are enacted in the public (Steiner-Khamsi 2002, 186). At the same time, these studies tell us little about the way in which the global is represented in young people's school-based experiences of care.

Overall then, the existing literature might lead us to expect that global citizenship might well be implicitly gendered in the same way as national notions of citizenship have been. Furthermore it may lead us to expect that there would be differences in the experiences of both girls and boys in single-sex and co-educational schools that are directed towards their formation as citizens. However, the existing literature does not present data which might allow us to test these propositions. Additionally, much existing data on the gendering of citizenship education tends to be qualitative or based on the analysis of texts (e.g. Stone 2000; Unterhalter 2000; Gordon et al. 2000; Asbrand 2008). This is not surprising given the foundational and theoretical questions with which such literature has tended to engage and the prominence placed by feminist researchers on qualitative research methods particularly action research, ethnography, personal testimonies, in-depth interviews, focus groups interviews, case studies, content/ textual analysis among others (HesseBiber and Leavy 2007). Nonetheless, this does mean that there is a lack of largescale, cross-sectional research in the field, and, as Oakley $(2000,299)$ has argued: 
Without quantitative methods, feminism as a political and social movement would not have got very far. Knowing about the oppression of women, the labour market, the health and welfare systems, political organisations and government, and the private world of the home and domestic relations...setting injustices right first requires a factual map of what has gone wrong.

In short then, this paper addresses three important gaps in our current understanding of gender and global citizenship education. It makes a significant contribution to the gender and citizenship education literature by questioning the ways in which the global can be and is layered into the gendered practice of citizenship education. Given the lack of data on the gendering of global citizenship it provides quantitative data on educational practices. Following Lynch and Lodge's claim that the ethos of single-sex schools is under-researched, it also adds to our knowledge in this field.

\section{Context of the Study}

Development Education offers schools alternative worldviews based on social justice and human rights that challenge the market-driven, neo-liberal view that education systems are expected to mediate to students in the context of the knowledge society (Hargreaves 2003). In the Irish context however, the status of interventions that do not count in the 'points race' for entry to higher education tends to be low as found for example by Murphy (2003) and Gleeson and Munnelly (2003) in relation to the Junior Certificate Civic Social and Personal Education programme. As the Irish Commission on the Points System $(1998,145)$ concluded, "a significant criticism of the points system is that students preparing for and taking the Leaving Certificate often focus to such an extent on the examination that many of their other activities are ignored”.

For historical reasons, largely related to the power of the Catholic Church in Irish education, more than half of Irish post-primary schools are privately-owned secondary or grammar-type schools (typically controlled by religious organisations) and 34.8 per cent of post-primary schools are completely single-sex.

\section{Methodology}

This research is based on the largest ever study of attitudes to development education and development issues carried out in Ireland. The study was funded by the 
Development Education Unit of Irish Aid (the Irish Government's body with responsibility for overseas development aid and development education). Data was collected from survey instruments administered to 119 school leaders/representatives and 2,588 second-year, second-level (Year 10 - aged 13/14) students. Using a sampling frame similar to that used in the Programme for International Student Assessment (PISA) study, a large sample of 120 (out of 743) schools was selected for the study in order to ensure a representative sample of students and teachers. Following withdrawals and replacements, 119 schools participated in the study.

For the completion of the 'school profile' survey, the principal or his/her nominee was interviewed by one of a team of 12 fieldworkers. Of the 119 schools, school profiles were collected in 118. Since student surveys could only be administered during timetabled class periods, arrangements were put in place to ensure that class groups were selected for survey completion at random, regardless of whether individual schools formed their class groups on the basis of streaming or mixed-ability. Written guidelines were provided to the fieldworkers indicating how to select classes in the case of both streamed and mixed-ability settings, in order to ensure that an 'ability' bias was not built into the sample. Since Irish schools and classes are relatively homogenous, the fact of having to draw a random sample of classes (rather than of pupils) meant there was a need for a proportionately larger sample of young people than might otherwise have been the case. In total, the survey was administered to 2,588 second-year students.

Boys made up 48.6 per cent of the sample with girls accounting for 51.4 per cent. Students in single-sex schools are slightly overrepresented in the sample, with students in co-educational schools accounting for 54.1 per cent of the sample as compared to 62.4 per cent of the population. Girls in single-sex schools make up 25.2 per cent of the sample as compared to 22.2 per cent of the population, and boys in single-sex schools make up 20.7 per cent of the sample as compared to 15.4 per cent of the population. Broadly speaking then, the sample is representative of the population of Irish post-primary school pupils.

Separate survey instruments were designed for the students and for school leaders. The instruments were largely developed $a b$ initio, with only Section $\mathrm{C}$ of the student questionnaire drawing to a significant extent on pre-existing questions. These surveys sought information regarding a range of independent variables and included items designed to establish attitudes towards and knowledge of development 
education. The surveys were circulated to key actors in the field for review and, following amendment, were piloted with school-age pupils in order to ensure readability and age-appropriate and culturally-appropriate language before final design and printing. The differences between the groups involved in piloting each instrument led to some differences between the questionnaires. For example, some of the activities identified in the school profile instrument were omitted or the language altered in the student questionnaire (see figure $1[\mathrm{a}]$ and $[\mathrm{b}]$ ). This was due to feedback during the piloting process on the appropriate wording for each group and due to a desire to shorten the student questionnaire where possible. The final student questionnaire was twenty-two pages long, and the school profile instrument was eleven pages in length (the full text of both questionnaires used can be found in Appendices II and VII of Gleeson et al., [2007]).

The school leaders' data collection instrument ('School Profile Instrument') consisted of a questionnaire/ interview schedule administered face-to-face by the fieldworker to the school principal or her/his nominee. The instrument, which is summarised in Figure 1(a), consisted of forty-seven questions or topics, sixteen of which were closed questions and typically contained multiple parts, and the remainder of which were open-ended questions or topics. Responses to open-ended questions were coded for statistical analysis.

The student questionnaire consisted of forty-five largely closed questions many with multiple parts - in nine sections. Sections A and B included a total of fifteen questions and collected a range of demographic data on a student's age, religion, country of birth, educational level and occupation of his/her parents/guardians. Section C included five questions and collected attitudinal data on her/his reported level of social distance from a range of minority groups, based upon Bogardus-type scales. Section D had seven questions and collected data on students' reported feelings about the Third World/developing countries. Section E had three questions and asked about her/his participation in activities that had a global poverty/ inequality focus. Section F had two questions and asked about the student's sources of information on global poverty/ inequality issues. Section $\mathrm{G}$ had five questions and asked about the extent to which Third World/development issues had been a part of the student's learning in post-primary school. Section $\mathrm{H}$ included five questions which assessed his/her level of general knowledge about Third World/developing world countries. Section I included three questions on whether or not they were 
optimistic about addressing global poverty/ inequality issues. The student data presented in this article derives from Section G, and key questions from that section are presented in Figure 1(b).

[Insert Figure 1(a) and (b)]

The data collected was based principally on self-report type questions and so care must be taken around the analysis of some of the data (i.e. they reflect what respondents say they remember rather than what actually took place). Furthermore, the surveys were not originally designed to capture information about or to test hypotheses about gender issues and global citizenship education; these were issues that emerged in the analysis of the data. This means that, in relation to gender and global citizenship, this data is more suited to exploring data and forming hypotheses than it is to testing hypotheses. It is in that spirit that the data is presented.

\section{Presentation of Findings}

The data presented here draws on two sources of information: the school profile data which gives an insight into the school's 'official' view as to the place of development education and global citizenship in the life of the school, and the student survey which gives a sense of the students' reports of their experience of development education and global citizenship in the life of the school. As such, this article looks at both what school leaders say happens in school, and at what pupils say about their experience of what schools do.

School Profile Data: A school will often identify itself as having a particular ethos. This ethos may or may not be reflected in practice. In order to get a sense of the school's stated ethos with respect to development education, the school spokespersons were asked to what extent development education was valued within their schools. This was asked as a single question and so the validity of the responses may not be as high as if a composite measure drawn from responses to multiple questions had been used. Nonetheless the responses are instructive and are presented in Table 1.

[Insert Table 1] 
As the question was a valid question for all schools, it makes sense to look at responses to the question as a proportion of all responses (rather than to focus attention on those for whom responses were written down by the fieldworkers). Out of 118 schools, 71 (60.2 percent) identified development education as being either 'very important' or 'as important as other subjects'. A further 4 schools (3.4 percent) reported it as 'featuring in the life of the school'. Given the central place of examination 'subjects' in the life of schools (Murphy 2003; Gleeson and Munnelly 2003; Gleeson 2010) and given that development education/ global citizenship education is not actually a subject in schools, this seems a remarkably high level of reported commitment.

In order to meet the assumptions for using chi-square to test if the stated level of commitment is associated with the gender of the school intake it is necessary to recode this data into 3 categories: 'very important', 'same as other subjects' 'less important or not stated'. Measured in this way, a chi-square tests shows the responses to this question are significantly associated with the gender intake of the school, with both boys' and girls' single-sex schools more likely to identify development education as very important, in comparison to co-educational schools $\left(\chi^{2}=12.259\right.$; $\mathrm{df}$ $=4 ; \mathrm{p}=0.016)$. Further analysis shows that single-sex schools are significantly more likely to state a higher level of commitment to development education than mixed schools $\left(\chi^{2}=9.23 ; \mathrm{df}=2 ; \mathrm{p}=0.01\right)$, but that, within single-sex schools, while the association between the reported levels of commitment to development education and the gender of intake is notable, it is not significant at the $\mathrm{p}<0.05$ level $\left(\chi^{2}=4.36\right.$; df $=2 ; \mathrm{p}=0.113)$.

As Chart 1 shows, boys' schools are most likely to identify that they regard development education as very important. It is also notable, however, that the pattern for boys' schools is a little different from other schools, with boys' schools being more likely to appear at both the top and at the bottom of the scale in comparison to other schools with the 'middle ground' being somewhat squeezed out in boys' schools.

[Insert Chart 1] 
As was noted above, this indicator relies on a subjective measure by the person responding on behalf of the school. Reports of actual activities that had taken place were also gathered. These are presented in Table 2 (below). It is evident from this data that 'fasting' (undertaken as a fundraising activity for the overseas development aid agencies Trócaire and Concern) is the development-related activity in which schools are most likely to engage, with over 95 percent of schools hosting a fast in the last two years. Over 60 percent of schools identified that they had engaged in a debate associated with the overseas development aid agency Concern within the last two years. Over 50 per cent identified that they have links with teachers or schools in a developing country. About four in every ten identified that they had held an event to celebrate Human Rights Day, and a similar number had acknowledged World AIDS Day. Only one school in six had held events around One World Week within the last two years.

[Insert Table 2]

[Insert Chart 2]

It was noted above that the gender intake of the school had a significant impact upon espoused values, with single-sex schools claiming to regard development education as very important more often than co-educational schools. It is worthwhile to compare this to a measure of reported actual activity in relation to development education. For this purpose a composite measure was developed, based on the eight questions presented in table 2. Using such composite measures is more robust and fair than using individual questions in isolation as it means one gets a much fuller picture of the level of activity in the school than would be supplied by a single measure. As table 3(a) shows, if we take this measure, the mean average number of activities reported as engaged in by schools is 3.64 out of a possible 8, with a standard deviation of 1.59 .

Again we find that gender intake of the school does have a notable impact. Interestingly, however, although boys' schools were the most likely to identify that development education was regarded as very important they also have the lowest levels of reported activity in relation to development education. Chart 2 shows that the median number of activities reported is higher for girls' schools and broadly similar for boys' schools and co-educational schools. Boys' schools are less likely to 
have reported a high level of activity and more likely to have a low level of reported activity than girls' schools. Co-educational schools span across the range from high levels of reported activity to low. The mean average number of reported activities engaged in by girls' schools is 4.3, while in boys' schools it is 3.18. Whether or not this difference is significant can be determined using ANOVA (as the data does not breach the assumption of homogeneity of variance for use of ANOVA). As can be seen in table 3(b), the association between gender of school intake and the level of development-related activity is significant at the $\mathrm{p}<0.05$ level $(\mathrm{p}=0.022)$. A Tukey HSD post hoc test (Table 4) shows a significant difference in levels of reported activity in girls' schools and boys' schools $(\mathrm{p}=0.031)$ and a notable if marginally non-significant, difference between girls' schools and co-educational schools ( $\mathrm{p}=$ 0.055).

[Insert Table 3]

[Insert Table 4]

The above data is all based on the survey interview with a school leader. While it tells us what the school claims to organise it does not tell us about young peoples' experience of what the school organises. It is to this that we now turn.

\section{Student survey:}

Students were asked questions about the activities which they undertake as part of their formal study in school. This data is presented in table 5. Gender of school intake is significantly associated with reporting that they had discussed 'fair trade and debt' and 'global warming and environmental destruction' in school. Further analysis shows that students in single-sex girls' schools are significantly more likely than students in single-sex boys' schools to report having discussed 'aid and development' $\left(\chi^{2}=7.161 ; \mathrm{df}=2 ; \mathrm{p}=0.028\right)$ (although the difference on this variable is largely explained by the pattern of 'no' and 'don’t know' responses), 'Irish Third World agencies' $\left(\chi^{2}=8.203 ; \mathrm{df}=2 ; \mathrm{p}=0.017\right)$, 'fair trade and debt' $\left(\chi^{2}=16.642 ; \mathrm{df}=2 ; \mathrm{p}=\right.$ $0.000)$, and 'hunger and famine' $\left(\chi^{2}=6.446\right.$; $\left.\mathrm{df}=2 ; \mathrm{p}=0.040\right)$. Students in single sex-girls schools are significantly more likely than students in co-educational schools to report having discussed 'fair trade and debt' $\left(\chi^{2}=16.813\right.$; $\left.\mathrm{df}=2 ; \mathrm{p}=0.000\right)$ and 
'global warming and environmental destruction' ( $\chi^{2}=6.854$; $\mathrm{df}=2$; $\mathrm{p}=0.032$ ). Students in boy's single-sex schools are significantly more likely than students in coeducational schools to reporting having discussed 'global warming and environmental destruction' $\left(\chi^{2}=6.667 ; \mathrm{df}=2 ; \mathrm{p}=0.036\right)$.

[Insert Table 5]

Students were also asked a range of questions related to their extra-curricular activities. The results of these questions are presented in Chart 3. It is evident that fundraising is the activity students most frequently say they undertake, with 34.4 per cent of students reporting undertaking fundraising very often or often, and two-thirds undertaking fundraising at least sometimes (this is consistent with the schools' claim that fasting in support of an agency is the most commonly organised activity). Special activities such as those to mark World AIDS day are reported to be undertaken often or very often by 14 per cent of students, and 13.5 per cent of students have reported taking part in debates on Third World issues either very often or often. The likelihood of a student saying they have engaged with at least some of these activities is related to the gender intake of their school; there is a significant association between the gender intake of the school and students reporting that they have engaged in special events to mark occasions such as World AIDS Day $\left(\chi^{2}=\right.$ 19.762; $d f=8 ; p=0.011)$. The relationship between the gender intake of school and students reporting being engaged in debates on Third World issues is notable, if marginally non-significant at the $\mathrm{p}<0.05$ level $\left[\chi^{2}=14.789 ; \mathrm{df}=8 ; \mathrm{p}=0.063\right]$ ).

Further analysis reveals that students in girls' schools are more likely to report that they have engaged in special events to mark occasions such as World AIDS Day when compared to both students in boys' schools $\left(\chi^{2}=13.941 ; \mathrm{df}=4 ; \mathrm{p}=0.007\right)$ and students in co-educational schools $\left(\chi^{2}=9.959\right.$; $\left.\mathrm{df}=4 ; \mathrm{p}=0.041\right)$. Students in boys' schools are significantly less likely to report that they have participated in debates on Third World issues than students in co-educational schools $\left(\chi^{2}=11.863 ; \mathrm{df}=4\right.$; $\mathrm{p}=0.018)$.

[Insert chart 3] 


\section{Discussion of Findings}

We noted above that schools can report themselves as having a particular ethos which may or may not be reflected in practice. When asked directly how much development education is valued in their school, school spokespersons typically responded that it is as an important aspect of school life. This is evident in that 60 per cent of school spokespersons identified that development education is at least as important as other subjects in the curriculum, despite the fact that development education does not appear as a subject in schools as such. A question like this, asked in an interview on development education of people who have been selected as spokespersons on development education for their school, always has the capacity to elicit what are perceived by the respondents to be socially desirable responses. To effectively evaluate this data it will be worthwhile to compare it to measures of reported activities.

It was noted above that the existing literature tells us little about how development education and global citizenship experiences differ for male and female learners. In at least some of the schools the apparently strong emphasis on development education does not translate into practice, at least as measured with respect to the curricular and extra-curricular activities in which they engage. Singlesex boys' schools are the ones most likely to rate themselves as having a strong emphasis on development education (Chart 1), and single-sex schools in general are significantly more likely to state a higher level of commitment to development education than co-educational schools. Yet, when actual reported activity is measured, single-sex boys' schools report the lowest levels of activity (Table 3[a]), levels of reported activity which are significantly lower than that of single-sex girls' schools. It is also clear that there are significant differences in the way in which pupils in single-sex girls' schools, co-educational schools and single-sex boys' schools experience development education and global citizenship education in practice. Given that the curriculum is a common one, shared between all schools (albeit with considerable opportunities for schools to make gender-based choices in what subjects to make available to pupils outside of a common core of subjects) it is perhaps not too surprising that the differences in the students' experience of the formal curriculum is limited. Nonetheless those in single-sex girls' schools were significantly more likely to have been exposed to concepts like aid, development, fair trade, international debt, hunger and famine than those in single-sex boys' schools. 
Clear differences between schools were also evident in relation to the developmentrelated extra-curricular activities available in girls' schools when compared to other school types, particularly with respect to special activity events such as marking World AIDS Day.

At its most superficial this suggests a need be cautious in drawing inferences from self-report measures of interest which are not triangulated against measures of activity. More substantively, however, it seems to indicate a significantly greater gap between rhetoric and reality (Gleeson 2004; 2010) in boys' schools when compared to girls' schools and co-educational schools. At another level, the findings reflect the ideological differences between boys', girls' and co-educational schools. Girls' schools reported participating in on average 4.3 development-related activities out of the 8 that were addressed in the survey. For boys' schools the average was 3.18, with co-educational schools occupying an intermediate position (3.5 activities on average). Lynch and Lodge (2002, 104-105) found that a sense of care was declining in the hidden curriculum of single-sex girls' schools, reporting that:

In our present study, while it was clear from the prizes given, the extracurricular activities undertaken and staff-student exchanges in the classrooms and elsewhere, that care for others was still an important value for girls especially, it did not seem to hold the same status as in the earlier study.

Feminist writers on citizenship (Hobson and Lister 2002; Lister 2003) and on citizenship education (Noddings 2003; McIntosh 2005) have highlighted the importance of a sense of care within a balanced account of citizenship. For these writers, 'care' is a necessary corrective to the notions of obligation and duty which is associated with a communitarian position, such as that of the 'Third Way' movement. On the other hand it has been argued that the focus on 'care' in girls' schools reflects a Christian Communitarian tradition (O’Sullivan 2005). Hannan and Boyle (1987) have argued that, while female religious orders traditionally placed an emphasis in their schools on personal development and social responsibility, male religious orders placed an emphasis on religious and moral formation with a priority being placed on academic goals. We found that students in single-sex girls' schools are significantly more likely than students in single-sex boys' schools to report having discussed subjects like 'Irish Third World agencies', 'fair trade and debt', and 'hunger and famine'. While - as we noted above - our surveys are more suited to exploring data and forming hypotheses than they are to testing hypotheses, our data suggests that 
there are still notable differences between the emphasis on care for the community and others in girls' and boys' single-sex schools, but also that this sense of care is being extended beyond local and national boundaries. In a context of growing globalisation, an analysis of global inequality and an engagement with global structures such as debt and fair trade now appear to be a part of the sense of citizenship that is articulated in girl's single-sex schools. While these issues are addressed in boys' schools and co-educational schools, such schools are less likely to report that they are involved in addressing these issues and students in such schools are less likely to report having engaged with them. In this sense, the data suggests a gendering of global citizenship education experiences.

Since the Catholic Church owned virtually all of the single-sex schools in the study, the findings suggest that there are fascinating gender differences within that body. Researchers have tended to see Catholic Church bodies as being having quite conservative impacts upon the education system (Inglis 1998; O’Sullivan 2005, 112 ff.). The data presented here reinforces Hannan and Boyle's (1987) contention that there are clear differences between the ethos in male and female Catholic foundations. More generally, some groups within the Catholic Church, driven by strong women such as Sister Teresa McCormack and Sister Stanislaus Kennedy, have been at the forefront of justice and equality work in Ireland. This political dimension seems to be reflected in the significantly greater likelihood of students in single-sex girls' schools becoming involved in discussions around issues such as fair trade, debt, and other issues. In a sense, the data presented here suggests something of a globalising of that politicised tradition.

\section{Conclusions}

Research into the intersection of globalisation, gender and citizenship education is at a relatively early stage. As a result, much of the existing research on global citizenship tends not to address gender while most of the literature on gender and citizenship tends not to address the global dimension. What research on this area does exist is based on textual analysis or qualitative studies. There is a clear absence of literature based upon large-scale cross sectional data which addresses both the gender and the global dimensions of citizenship. Our research addresses this gap by providing data from a large scale cross-sectional study of the development education / global citizenship experiences in both single-sex and co-educational schools. 
The findings highlight the significance of the influence of contextual factors in education, in this case the institutional ideologies of second-level schools seen from the perspective of gender. As Cornbleth $(1990,6)$ says: “Curriculum as practice cannot be understood adequately or changed substantially without attention to its setting or context." In this respect, the globalisation of school experiences remains an intrinsically localised event. In attending to the development of a sense of citizenship or identity which is reflexive and unbounded by national borders, (while at the same time being shaped by national-level responses to globalisation [Tormey, 2006]), we cannot ignore the ways in which different school contexts and institutional ideologies provide filters through which notions of the personal, the national and the global are framed. Indeed, while this data is drawn from the Irish context, it raises clear questions that could equally be applied to single-sex schools in other jurisdictions and to schools controlled by religious groups in other countries.

Lynch has suggested that girls' schools have traditionally encouraged students to take on responsibility for care of their environment and their social world. The data here suggests an extension of that role to include taking responsibility for inequality and poverty in the wider world. It may be that such an extension is in part motivated by a politicised ethic of liberation which is found in some Catholic groups. Whatever its source, its effects are noticeable and, while notions of national citizenship may well have been traditionally framed in ways which excluded women, the domain of global citizenship education is, it appears, being significantly framed by them.

\section{References}

Anderson, B. 1983. Imagined Communities, Reflections on the Origin and Spread of Nationalism. London: Verso.

Appiah, K.A. 2006. Cosmopolitanism, Ethics in a World of Strangers. London: Penguin.

Asbrand, B. 2008. How adolescents learn about globalisation and development. In Development Education, Debates and Dialogues, ed. Bourn, D. London: Institute of Education: 28-45.

Arnot, M. and J.A. Dillabough. 2000. Introduction. In Challenging Democracy, International Perspectives on Gender, Education and Citizenship eds. Arnot, M. and J-A. Dillabough, J-A. London: RoutledgeFalmer: 1-19.

Bellamy, R. 2008. Citizenship, A Very Short Introduction. Oxford: Oxford University Press.

Bourn, D. ed. 2008. Development Education, Debates and Dialogues. London: Institute of Education.

Commission on the Points System. 1998. Consultative Process - Background Document. Dublin:Stationery Office. 
Cornbleth, C. 1990. Curriculum in Context. London: Falmer.

Daly, M. 2003. Wives, mothers and citizens: the treatment of women in the 1935 nationality and citizenship act. Eire-Ireland: Journal of Irish Studies, 38, 3/4: 244-263.

Davies, I., M. Evans and R. Reid. 2005. Globalising Citizenship Education?: A Critique of "Global Education" and "Citizenship Education”. British Journal of Educational Studies 53, No. 1: 66 - 89.

Drudy, S. and K. Lynch,K. 1993. Schools and Society in Ireland. Dublin: Gill and MacMillan.

Fennell,S. and M. Arnot, M. eds. 2008. Gender Education and Equality in Global Contexts: Conceptual Frameworks and Policy Perspectives. London: Routledge.

Giddens, A. 1991. Modernity and Self-Identity, Self and Society in the Late Modern Age. Cambridge: Polity.

Gilligan, C. 1982. In a different voice. Cambridge, MA: Harvard University Press.

Gleeson, J. 2004. Cultural and political contexts of Irish post-primary curriculum: influences, interests and issues. In Curriculum and Ideology, Irish Experience, International Perspectives, ed. Sugrue, C. Dublin: Liffey Press, p 101-140.

Gleeson, J. 2010. Curriculum in Context; Partnership, Power and Praxis in Ireland. Oxford: Peter Lang.

Gleeson, J. and J. Munnelly. 2003. Developments in citizenship education in Ireland: context, rhetoric and reality. Unpublished paper read at International Civic Education Conference, New Orleans.

Gleeson, J., King, P., O’Driscoll, S., \& Tormey, R. (2007) Development Education in Irish Post-Primary Schools, knowledge, attitudes and activism. Shannon and Limerick: Shannon Curriculum Development Centre and Curriculum Evaluation and Policy Research Unit, University of Limerick.

Gordon, T., J. Holland and E. Lahelma. 2000. From Pupil to Citizen, A gendered route. In Challenging Democracy, International Perspectives on Gender, Education and Citizenship, eds. Arnot, M. and J-A. Dillabough. London: RoutledgeFalmer: 187-203.

Hannan, D. with M. Boyle, M. 1987. Schooling Decisions: The Origins and Consequences of Selection and Streaming in Irish Post-Primary Schools. Dublin: ESRI.

Hargreaves, A 2003. Teaching in the Knowledge Society Buckingham: Open University Press.

Hesse-Biber, S.N., and P. Leavy. 2007. Feminist Research Practice: A Primer: Thousand Oaks, California: Sage.

Hobson, B. and R. Lister. 2002. Citizenship. In Contested Concepts in Gender and Social Politics, eds. Hobson, B., J. Lewis, B. Siim. Cheltenham: Edward Elgar: 23-54.

Hogan, D. and R. Tormey. 2008. A perspective on the relationship between development education and education for sustainable development. Policy and Practice, A Development Education Review 6: 5-16.

Ibrahim, T. 2005. Global citizenship education: mainsteaming the curriculum?' Cambridge Journal of Education 35, No. 2: 177 - 194.

Inglis, T. 1998. Moral Monopoly, the rise and fall of the Catholic Church in modern Ireland. Dublin: University College Dublin Press.

Lentin, R. 1998. 'Irishness', the 1937 Constitution, and Citizenship: a gender and ethnicity view. Irish Journal of Sociology, 8: 5-24. 
Lister, R. 2003. Citizenship, Feminist Perspectives. Second Edition New York: Palgrave Macmillan.

Lynch, K. 1989a. Republic of Ireland. In Girls and Young Women, ed. Wilson, M. Oxford: Pergamon, pages 115-136.

Lynch, K. 1989b. The ethos of girls' schools: an analysis of difference between male and female schools' Social Studies, Vol. 10, pages 11-31.

Lynch, K. 1989c. The Hidden Curriculum. London: Falmer.

Lynch, K. and A. Lodge. 2002. Equality and Power in Schools: Redistribution, Recognition and Representation. London: RoutledgeFalmer.

McIntosh, P. 2005. Gender Perspectives on Educating for Global Citizenship. Educating Citizens for Global Awareness, ed. Noddings, N. New York: teachers College Press: 22-40.

Mac an Ghaill, M. 1994. The Making of Men, Masculinities Sexualities and Schooling Buckingham: Open University Press.

Murphy, D.A. 2003. Civics Revisited? An Exploration of the Factors Affecting the Implementation of CSPE in Five Post-Primary Schools. Unpublished dissertation submitted to the Education Department, National University of Ireland, Maynooth, in part fulfilment of the requirements for the Master of Education Degree.

Noddings, N. 2003. Caring, a feminine approach to ethics and moral education, second edition. Berkley CA: University of California Press.

Nussbaum, M.C. 2008. Towards a Globally Sensitive Patriotism. Daedalus, 137, Issue 3, 78-94.

Oakley, A. 2000. Experiments in Knowing: Gender and Method in Social Sciences, Cambridge: Polity.

O'Connor, S. 2008. 'Alien Family': The impact of the Aliens Act 1935 and Subsequent Orders on the Family in Ireland, 1933-1945. History of the Family, 13: 384-394.

On Lee, W. 2002. The Emergence of New Citizenship: Looking Into the Self and Beyond the Nation. In New Paradigms and Recurring Paradoxes in Education for Citizenship: An International Comparison, eds. Steiner-Khamsi, G., J. Torney-Purta and J. Schwille. Oxford: Elsevier Science Ltd, 37-61.

Osler, A. ed. 1994. Development Education; Global Perspectives in the Curriculum. London: Cassell.

Osler, A. and H. Starkey. 2005. Changing Citizenship, Democracy and Inclusion in Education. Maidenhead: Open University Press.

O’Sullivan, D. 2005. Cultural Politics and Irish Education since the 1950s, Policy Paradigms and Power. Dublin: Institute of Public Administration.

Regan, C. and S. Sinclair. 2006. Engaging development - learning for a better future? In 80:20 Development in an Unequal World $5^{\text {th }}$ Edition, ed. Regan, C. Dublin: 80:20 Educating and Acting for a Better World, Ireland: 107-120.

Steiner-Khamsi, G. 2002. Spheres of citizenship. In New Paradigms and Recurring Paradoxes in Education for Citizenship: An International Comparison, eds. Steiner-Khamsi, G., J. Torney-Purta and J. Schwille. Oxford: Elsevier Science Ltd, 179 -206.

Stone, L. 2000. Embodied identity: citizenship education for American girls. In Challenging Democracy, International Perspectives on Gender, Education and Citizenship, eds. Arnot, $\mathrm{M}$. and J-A. Dillabough. London: RoutledgeFalmer: 73-87. 
Tormey, R. 2003. Teaching Social Justice: Intercultural and Development education perspectives on education's context, content and methods. Limerick and Dublin: Centre for Educational Disadvantage Research and Ireland Aid.

Tormey, R. 2006. The construction of national identity through primary school history: the Irish case. British Journal of Sociology of Education 27, No. 3: 311-324.

Unterhalter, E. 2000. Transnational visions of the 1990s: Contrasting views of women, education and citizenship. In Challenging Democracy, International Perspectives on Gender, Education and Citizenship, eds. Arnot, M. and J-A Dillabough. London: RoutledgeFalmer: 87-103.

Voet, R. 1998. Feminism and Citizenship. London: Sage. 
Figure 1(a) School Profile Instrument/ Interview Schedule

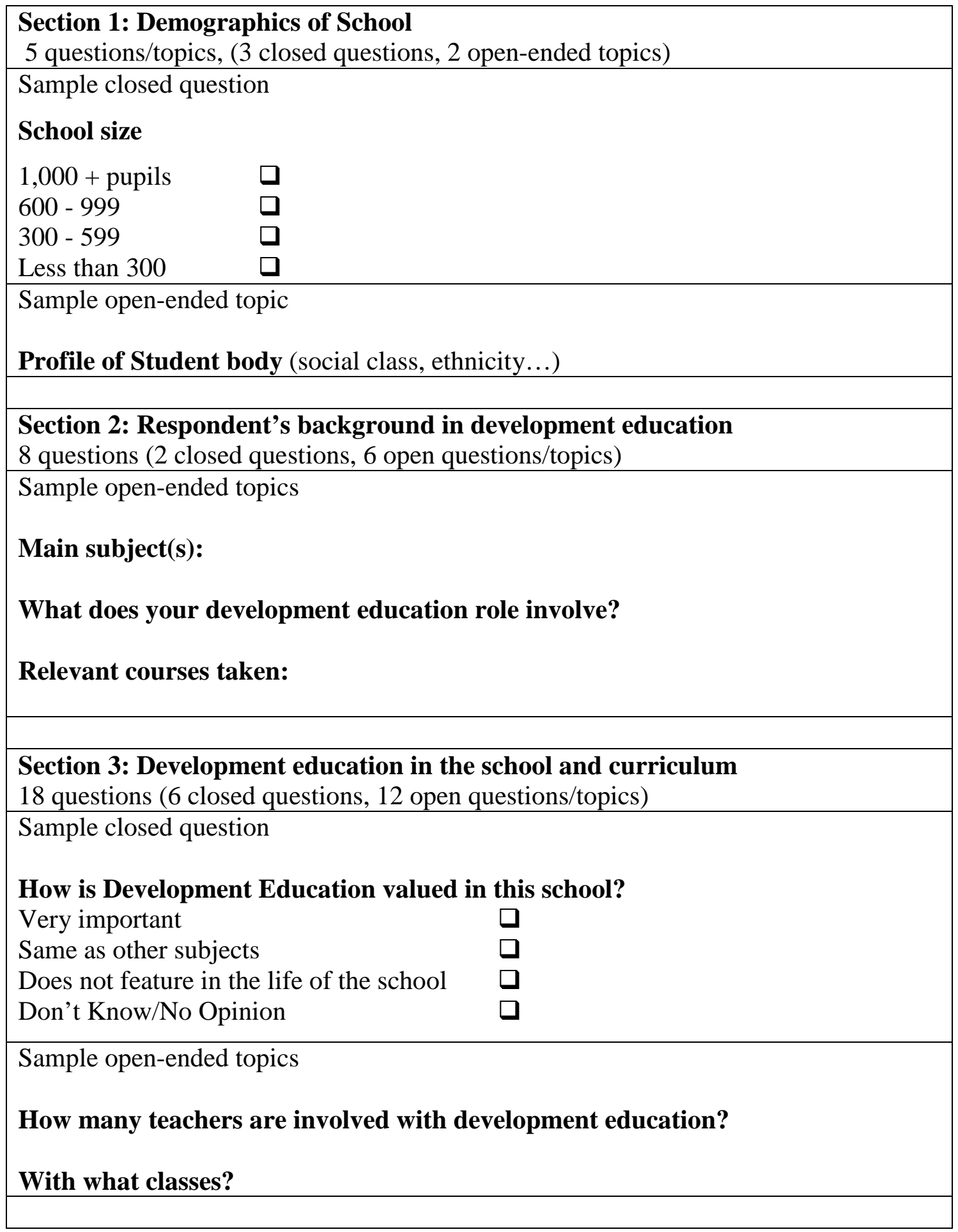


Figure 1(a) continued. School Profile Instrument/ Interview Schedule Section 4: Development education activities in the school 16 questions (5 closed questions, 11 open questions/topics)

Sample closed question

In the last two years, which if any of the following activities were marked in your school?

Mission Alive

Yes $\square$

No $\square$

Don’t know $\square$

One World Week

Yes $\square$

No $\square$

Don't know $\square$

Concern debate

Yes $\square$

No $\square$

Don't know

Concern/Trócaire Fast

Yes $\square \quad$ No $\square$

Don't know

International trip to a developing

$\begin{array}{llll}\text { Country } & \text { Yes } & \text { No } \square & \text { Don't know }\end{array}$

World-AIDS Day

Yes

No $\square$

Don’t know

International Human Rights

Day

Yes

No $\square$

Don’t know

Sample open-ended topics

Who gets involved in these activities (teachers' subjects, roles, characteristics)?

Do you have links with schools/teachers in developing countries?

If so, what form do these links take? 
Figure 1(b) Selection of items from Section G of Student Questionnaire

Q. 34 Have you discussed any of the following topics in school?

(please tick one box for each)

\section{Don't Know}

Aid and Development

Irish Third World Agencies

Fair trade and debt

Global warming and environmental destruction

Irish missionaries

Hunger and famine

Racism, refugees and migration

Other

Yes No

Q. 35 When Third World countries come up for discussion in school or in some other setting, how willing are you to participate?

(please tick one box)

$\begin{array}{ccccc}\text { Very } & \text { Willing } & \text { Somewhat } & \text { Unwilling } & \text { Very } \\ \text { Willing } & & \text { willing } & & \text { Unwilling } \\ \square & \square & \square & \square & \square\end{array}$

Q. 36 Since you started in post-primary school, have you participated in any of the activities listed below?

(Please tick one box for each statement)

Fund raising for a Third World cause

$\begin{array}{llllll}\text { Very Often } & \text { Often } & \text { Sometimes } & \text { Seldom } & \text { Never } & \text { Unsure } \\ \square & \square & \square & \square & \square & \square\end{array}$

Debates on Third World issues

$\begin{array}{llllll}\text { Very Often } & \text { Often } & \text { Sometimes } & \text { Seldom } & \text { Never } & \text { Unsure } \\ \square & \square & \square & \square & \square & \square\end{array}$

Mission week activities

$\begin{array}{llllll}\text { Very Often } & \text { Often } & \text { Sometimes } & \text { Seldom } & \text { Never } & \text { Unsure } \\ \square & \square & \square & \square & \square & \square\end{array}$

Special activities to mark events like World-AIDS Day

Very Often Often Sometimes Seldom Never Unsure

Other related activities (please specify) 
Table 1: How is development education valued in this school?

\begin{tabular}{|l|r|r|r|}
\hline & $\begin{array}{l}\text { Number of } \\
\text { schools }\end{array}$ & $\begin{array}{l}\text { Percentage } \\
\text { of those that } \\
\text { answered the } \\
\text { question }\end{array}$ & $\begin{array}{l}\text { Percentage } \\
\text { of all schools }\end{array}$ \\
\hline Very important & 37 & 39.8 & 31.4 \\
\hline Same as other subjects & 34 & 36.6 & 28.8 \\
\hline Features in the life of the school & 4 & 4.3 & 3.4 \\
\hline $\begin{array}{l}\text { Does not feature in the life of the } \\
\text { school }\end{array}$ & 11 & 11.8 & 9.3 \\
\hline Don't know/ No opinion & 7 & 7.5 & 5.9 \\
\hline No recorded response & 25 & & 21.2 \\
\hline Total & 118 & $100 \%$ & $100 \%$ \\
\hline
\end{tabular}


Chart 1: How is development education said to be valued in schools by gender intake

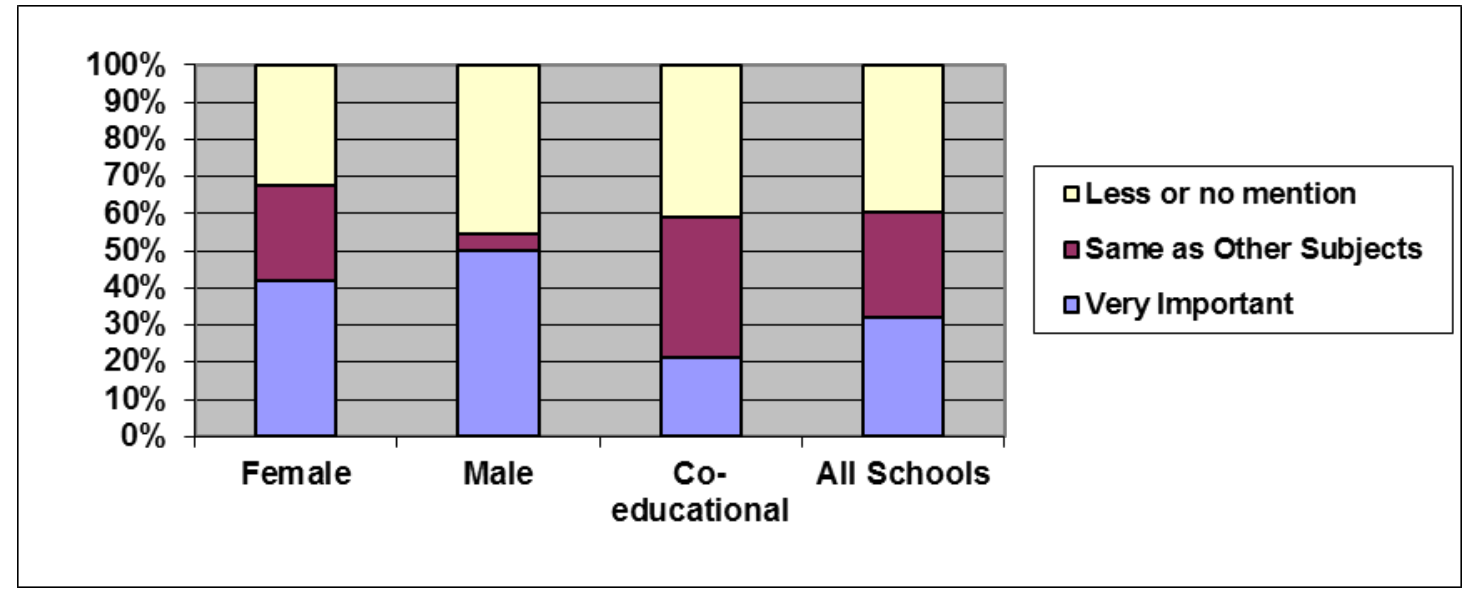


Table 2: Development education related activities engaged in by schools

\begin{tabular}{|l|l|l|}
\hline \multirow{2}{*}{ Schools which reported that they have: } & \multicolumn{2}{|l}{$\begin{array}{l}\text { Schools that answered } \\
\text { 'yes' to each question }\end{array}$} \\
\cline { 2 - 3 } & $\begin{array}{l}\text { Number } \\
\text { (out of } \\
\text { 118) }\end{array}$ & Per cent \\
\hline $\begin{array}{l}\text { had a fast in support of an aid agency within the last } \\
\text { two years }\end{array}$ & 113 & 95.8 \\
\hline $\begin{array}{l}\text { had a debate organised by the aid agency Concern } \\
\text { within the last two years }\end{array}$ & 72 & 61.0 \\
\hline links with schools/ teachers in developing countries & 61 & 51.7 \\
\hline marked Human Rights Day within the last two years & 50 & 42.4 \\
\hline marked World AIDS Day within the last two years & 46 & 39.0 \\
\hline achieved 'green flag' status for environmental work & 34 & 28.8 \\
\hline $\begin{array}{l}\text { marked an event in support of religious missions } \\
\text { (Mission Alive) within the last two years. }\end{array}$ & 33 & 28.0 \\
\hline marked One World Week within the last two years & 21 & 17.8 \\
\hline
\end{tabular}


Chart 2: Levels of reported development-related activity in the school, compared by gender intake of school

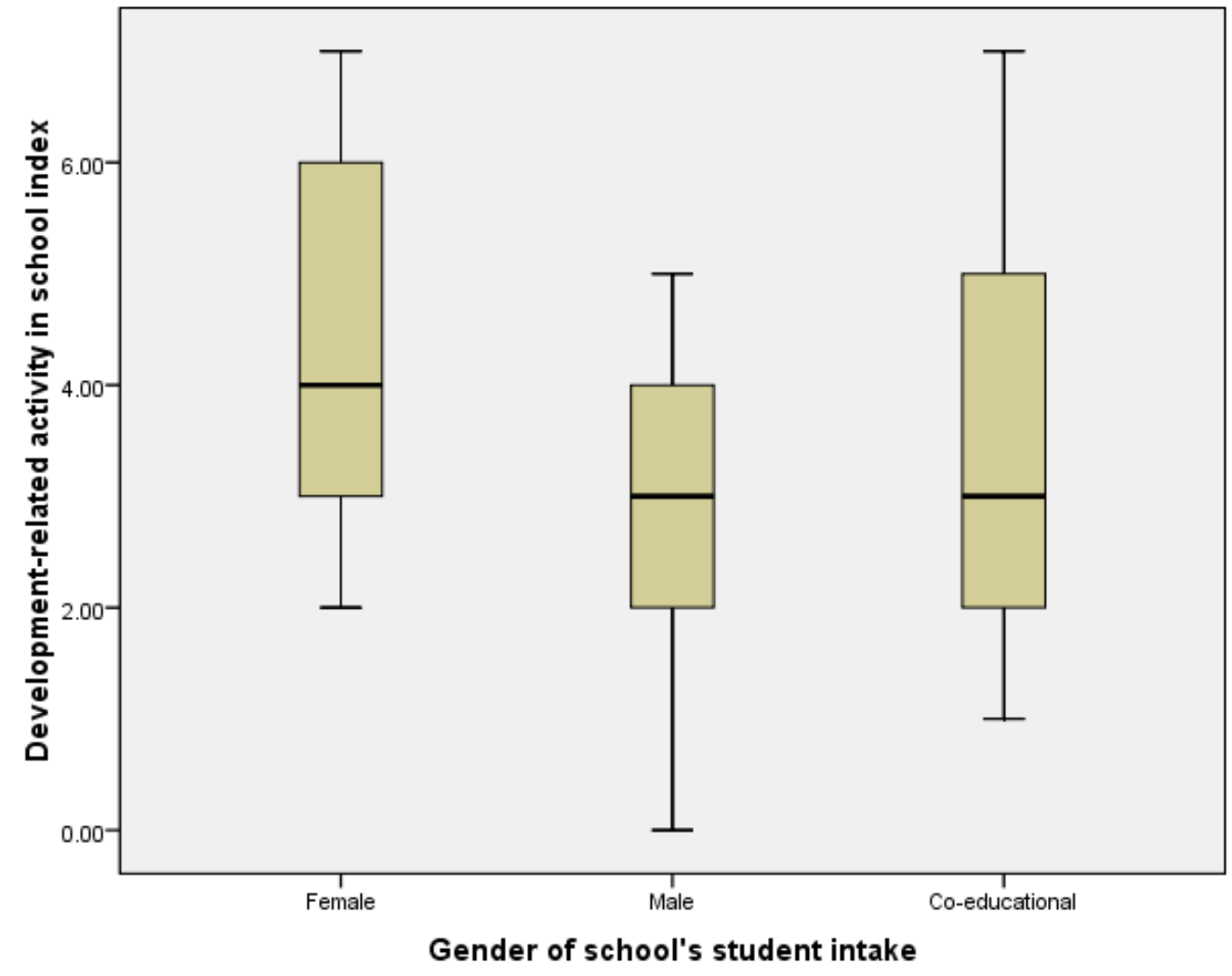


Table 3(a): Levels of reported development-related activity in the school, compared by gender intake of school

\begin{tabular}{|c|c|c|c|}
\hline $\begin{array}{l}\text { Gender of School } \\
\text { Intake }\end{array}$ & $\mathbf{N}$ & Mean & $\begin{array}{l}\text { Standard } \\
\text { deviation }\end{array}$ \\
\hline Girls' Schools & 30 & 4.30 & 1.66 \\
\hline Boys' Schools & 22 & 3.18 & 1.47 \\
\hline $\begin{array}{l}\text { Co-educational } \\
\text { Schools }\end{array}$ & 66 & 3.50 & 1.53 \\
\hline All Schools & 118 & 3.64 & 1.59 \\
\hline
\end{tabular}

Table 3(b): Levels of reported development-related activity in the school, compared by gender intake of school (ANOVA)

\begin{tabular}{|l|l|l|l|l|l|}
\hline & $\begin{array}{l}\text { Sum of } \\
\text { Squares }\end{array}$ & df & $\begin{array}{l}\text { Mean } \\
\text { square }\end{array}$ & F & Sig. \\
\cline { 1 - 4 } Between groups & $\mathbf{1 8 . 9 7 8}$ & 2 & $\mathbf{9 . 4 8 9}$ & \multirow{2}{*}{3.924} & \multirow{2}{*}{.022* } \\
\cline { 1 - 3 } Within groups & $\mathbf{2 7 8 . 0 7 3}$ & $\mathbf{1 1 5}$ & $\mathbf{2 . 4 1 8}$ & & \\
\hline Total & $\mathbf{2 9 7 . 0 5 1}$ & $\mathbf{1 1 7}$ & & & \\
\hline
\end{tabular}


Table 4: Tukey Post Hoc Test for differences of means of development-related activity in the school, compared by gender intake of school

\begin{tabular}{|l|l|r|r|r|}
\hline & & \multicolumn{1}{l|}{$\begin{array}{l}\text { Mean } \\
\text { Difference }\end{array}$} & $\begin{array}{l}\text { Standard } \\
\text { Error }\end{array}$ & \multicolumn{1}{l|}{ Sig. } \\
\hline Girls' Schools & Boys' Schools & $1.11818^{*}$ & 0.43648 & $0.031^{*}$ \\
\cline { 2 - 5 } & $\begin{array}{l}\text { Co-educational } \\
\text { Schools }\end{array}$ & 0.80000 & 0.34240 & 0.055 \\
\hline Boys' Schools & Girls' Schools & $-1.11818^{*}$ & 0.43648 & $0.031^{*}$ \\
\cline { 2 - 5 } & $\begin{array}{l}\text { Co-educational } \\
\text { Schools }\end{array}$ & -0.31818 & 0.38281 & 0.684 \\
\hline $\begin{array}{l}\text { Co-educational } \\
\text { Schools }\end{array}$ & Girls' Schools & -0.80000 & 0.34240 & 0.055 \\
\cline { 2 - 5 } & Boys' Schools & 0.31818 & 0.38281 & 0.684 \\
\hline
\end{tabular}

Note: * is significant at the $\mathrm{p}<0.05$ level 
Table 5: Percentage of student reporting that they have discussed a range of development-related issues in schools

\begin{tabular}{|l|l|l|l|l|l|}
\hline & $\begin{array}{l}\text { Girls' } \\
\text { schools }\end{array}$ & $\begin{array}{l}\text { Boys's } \\
\text { schools }\end{array}$ & $\begin{array}{l}\text { Co- } \\
\text { educationa } \\
\text { l schools }\end{array}$ & df & $\begin{array}{l}\text { Chi- } \\
\text { square } \\
\text { (p) }\end{array}$ \\
\hline $\begin{array}{l}\text { Aid and } \\
\text { development }\end{array}$ & 64.9 & 65.5 & 63.8 & 4 & $\begin{array}{l}8.261 \\
(\mathrm{p}=0.082)\end{array}$ \\
\hline $\begin{array}{l}\text { Irish Third World } \\
\text { Agencies }\end{array}$ & 52.6 & 48.2 & 51.0 & 4 & $\begin{array}{l}8.275 \\
(\mathrm{p}=0.082)\end{array}$ \\
\hline Fair Trade and Debt & 71.9 & 62.5 & 62.3 & 4 & $\begin{array}{l}26.318 \\
(\mathrm{p}=0.000) \\
* *\end{array}$ \\
\hline $\begin{array}{l}\text { Global Warming and } \\
\text { Environmental } \\
\text { Destruction }\end{array}$ & 87.0 & 86.6 & 82.3 & 4 & $\begin{array}{l}11.345 \\
(\mathrm{p}=0.023) \\
*\end{array}$ \\
\hline $\begin{array}{l}\text { Irish Missionaries } \\
\text { Hunger and Famine }\end{array}$ & 47.2 & 44.9 & 46.1 & 4 & $\begin{array}{l}3.730 \\
(\mathrm{p}=0.444)\end{array}$ \\
\hline $\begin{array}{l}\text { Racism, refugees, } \\
\text { Migration }\end{array}$ & 82.4 & 83.0 & 80.7 & 4 & $\begin{array}{l}9.208 \\
(\mathrm{p}=0.056)\end{array}$ \\
\hline
\end{tabular}

Note: * is significant at the $\mathrm{p}<0.05$ level; ** is significant at the $\mathrm{p}<0.01$ level 
Chart 3 Frequency with which a range of extra-curricular tasks addressing Third World issues were undertaken since starting post-primary school

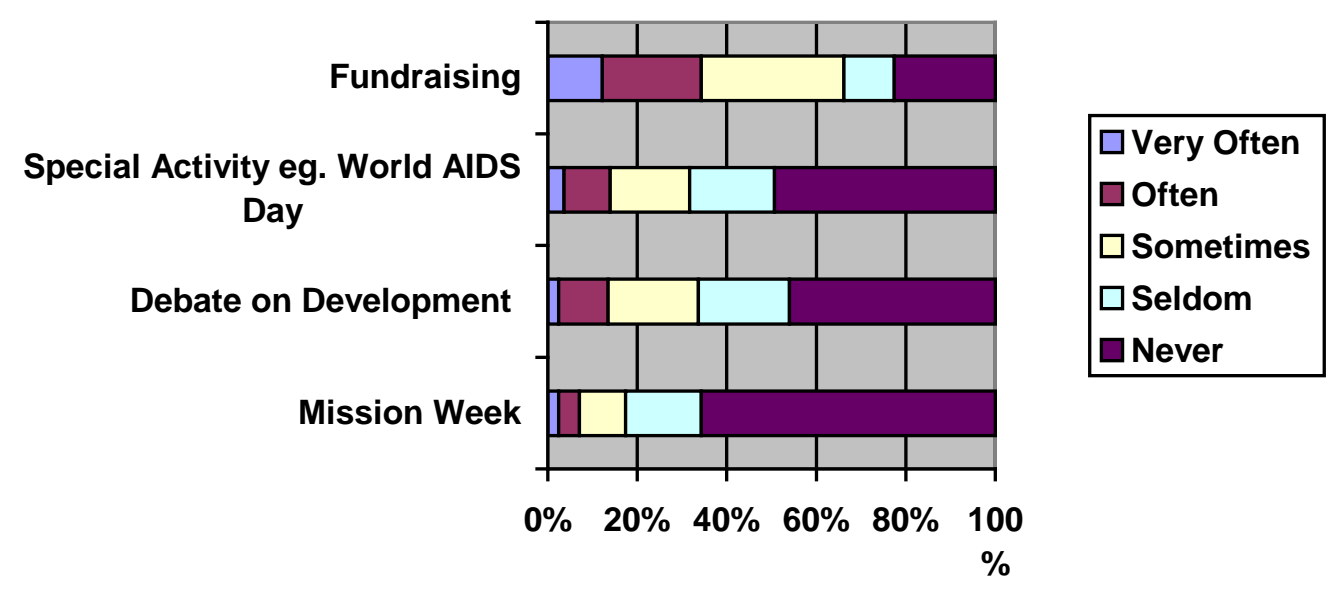

